ROCZNIKI TEOLOGICZNE

Tom LXVII, zeszyt $9-2020$

DOI: http://dx.doi.org/10.18290/rt20679-4

\title{
NIEOMYLNOŚĆ BISKUPA RZYMU JAKO PROBLEM EKLEZJOLOGICZNY AD INTRA I AD EXTRA
}

\author{
INFALLIBILITY OF THE BISHOP OF ROME \\ AS AN ECCLESIAL ISSUE $A D$ INTRA AND $A D E X T R A$
}

\begin{abstract}
The infallibility of the Bishop of Rome has never been universally accepted in the Church. Controversies were present during the council debate after the solemn 1870 declaration but, even today, not all doubts have been clarified. They arose from the ecclesiological reflection within the Church, but were also a consequence of the ecumenical dialogue with other Christian communities. The aim of this paper is to present the ecclesial issues that arose soon after Vatican Council I, which led to the schism and to the emergence of the Old Catholic Church, and a similar situation after Vatican Council II, exemplified by the case of H. Küng. There is a significant theological issue of the relation between Church infallibility in the transmission of the saving truth and the papal infallibility in this regard. A key question arises from it: is the Bishop of Rome independent of the Church while announcing the truth with the official stamp of infallibility, or is he just expressing the truth developed within the community of faith? The present reflection and the answer to these questions places the papal subjectivity within the broad spectrum of the Church, anchoring his office in the dimension of the collegium of bishops and of the whole community of believers, who have a supernatural sense of faith. By this train of thought, it is possible to abandon understanding infallibility as a tragedy and to see it as a gift and charisma of the Holy Spirit.
\end{abstract}

Key words: infallibility; Church; pope; dogma; ecumenism.

\section{WSTĘP}

Nieomylność Biskupa Rzymu, jako prawda dogmatyczna nigdy nie miała w Kościele jednomyślnej akceptacji. Kontrowersje obecne były na etapie debaty

Ks. dr hab. MAREK ŻMUDZiŃSKI, prof. UWM - Katedra Teologii Fundamentalnej, Dogmatycznej i Moralnej, Wydział Teologii Uniwersytetu Warmińsko-Mazurskiego w Olsztynie; e-mail: marek.zmudzinski@uwm.edu.pl; https://orcid.org/0000-0002-1759-877X. 
soborowej, po uroczystej proklamacji 1870 r., ale również dziś nie wszystkie wątpliwości zostały wyjaśnione. Wynikały one zarówno $\mathrm{z}$ refleksji eklezjologicznej wewnątrz Kościoła, jak i również z prowadzonego dialogu ekumenicznego z wyznawcami innych wspólnot chrześcijańskich. Celem artykułu jest ukazanie trudności eklezjalnych tuż po zakończeniu Vaticanum I, które doprowadziły do schizmy i powstania Kościoła starokatolickiego, oraz analogicznej sytuacji po Vaticanum II, których egzemplifikacją jest przypadek H. Künga. Istotny problem teologiczny zogniskowany jest na ukazaniu relacji nieomylności Kościoła w przekazywaniu prawdy zbawczej do nieomylności papieża. Wynika z tego kluczowe pytanie: czy Biskup Rzymu ogłaszając prawdę z formalną rangą nieomylności jest niezależny od Kościoła, czy jest wyrazicielem prawdy, która wypracowana została we wspólnocie wiary? Dzisiejsza refleksja i jednocześnie odpowiedź na powyższe pytania umiejscawia podmiotowość papieża w szerokim spektrum Kościoła, zakotwiczając jego urząd w wymiarze kolegium biskupiego oraz całej wspólnoty wierzących, obdarzonej nadprzyrodzonym zmysłem wiary. Taki kierunek myślenia pozwala porzucić rozumienie nieomylności jako tragedii, a widzieć ją jako dar i charyzmat Ducha Świętego.

\section{INFALLIBILITAS - POJĘCIE NIEOMYLNOŚCI}

W najogólniejszym sensie nieomylność rozumie się jako przymiot osoby, społeczności czy też dzieła umożliwiający rozpoznawanie i przekazywanie prawdy ${ }^{1}$. Dookreślając tę formułę, należy pamiętać, że nieomylność jako taka pokrywa się z pojęciem podwójnej bezbłędności: prawnej i faktycznej. Jest to więc sytuacja, w której nieomylnym jest ten, kto nie tylko aktualnie nie błądzi, ale kto w ogóle, albo przynajmniej w niektórych okolicznościach, czy wypełniając pewne nieodzowne warunki, zbłądzić nie może. W takim rozumieniu przede wszystkim nieomylny jest człowiek, a dopiero następczo akt danej osoby ${ }^{2}$.

W aspekcie ściśle chrześcijańskim nieomylność traktuje się jako charyzmat, czyli nadprzyrodzony dar pochodzący od Boga, związany z asystencją Ducha Świętego, który gwarantuje wolność od popełniania błędów w sprawach wiary i moralności. Został on udzielony przez Jezusa Chrystusa całemu Kościołowi,

\footnotetext{
${ }^{1}$ Elżbieta KASJANIUK, „Nieomylność”, w Encyklopedia katolicka, t. XII (Lublin: TN KUL, 2009), 1148.

${ }^{2}$ Lucjan BALTER, Nieomylność encyklik papieskich. Studium teologiczno-historyczne (Warszawa: Akademia Teologii Katolickiej, 1975), 18-19.
} 
co wynika z obietnicy życiodajnego Parakleta-Ducha Prawdy (J 14,17), który przypomina Kościołowi co nauczał Jezus (J 14,26) i prowadzi go do całej prawdy (J 16,13). Można dodać, że dzięki Duchowi Prawdy Kościół jest „filarem i podporą prawdy" (1 Tym 3,15). Mając też na uwadze obietnicę asystencji Zbawiciela (,to Ja jestem z wami przez wszystkie dni aż do skończenia świata” Mt 28,20), można za św. Ireneuszem nazwać Kościół „Domem Prawdy”, w którym wykluczone jest wszelkie fałszywe nauczanie ${ }^{3}$. Biblijny aspekt uzupełniony być powinien współczesnymi wypowiedziami Kościoła, które bez wątpliwości potwierdzają, iż nieomylność jest zawsze uzależniona od Ducha Świętego ${ }^{4}$ oraz oparta na partycypacji w Prawdzie, którą uosabia sam Zbawiciel ${ }^{5}$.

Samo pojęcie „nieomylność” pojawiło się stosunkowo późno, gdyż dopiero w XIII wieku, choć należy pamiętać, na co zwraca uwagę M. Rusecki, że świadomość Kościoła w formie implikatywnej zawsze je posiadała. Choć więc teksty nowotestamentalne oraz egzegeza biblijna nie mówią wprost o charyzmacie nieomylności, to nie oznacza bynajmniej, by nie występowała świadomość jej istnienia wśród wyznawców Jezusa Chrystusa ${ }^{6}$.

Należy podkreślić, że nieomylność nie jest wyrazem nowego objawienia ani natchnienia, lecz wewnętrzną strukturą chrześcijaństwa, polegającą na prawdzie i obiektywności oraz jest prostą konsekwencją daru Objawienia. Łączy ona w sobie patrystyczne terminy, takie jak nienaruszalność treściową wiary (incolumitas fidei), jej pewność (certitudo) i bezbłędność (inerrantia) oraz autentyczność wiary (authenticitas fidei) i jak pisze Cz. Bartnik, choć nazwa ta nie jest zbyt szczęśliwa, to jednak zawiera w sobie moc rzeczywistości i jest warunkiem realności, trwałości i wartości dla życia osobowego wiary, poznania i nauki objawionej ${ }^{7}$.

\footnotetext{
${ }^{3}$ IRENEUSZ z LyONU, Adversus haereses III, 24, 2, seria: Antologia patrystyczna, red. Andrzej Bober (Kraków: Wydawnictwo Apostolstwa Modlitwy, 1966), 48.

${ }^{4}$ Mysterium Ecclesiae. Deklaracja o katolickiej doktrynie o Kościele przeciw niektórym wspótczesnym błędom, w W trosce o petnię wiary. Dokumenty Kongregacji Nauki Wiary 19661994 (Tarnów: Biblos, 1995), 56.

${ }^{5}$ KKK 889.

${ }^{6}$ Marian RuSECKI, Traktat o Objawieniu (Kraków: Wydawnictwo Księży Sercanów, 2007), 556.

${ }^{7}$ Czesław Stanisław BARTNIK, Dogmatyka, t. II (Lublin: Wydawnictwo KUL, 2003), 235.
} 


\title{
2. DOGMAT O NIEOMYLNOŚCI PAPIEŻA
}

Dogmat o nieomylności papieża został formalnie ogłoszony na Vaticanum I łącznie z dogmatem o prymacie 18 lipca 1870 r. w konstytucji dogmatycznej Pastor aeternus: „Biskup Rzymski, gdy mówi ex cathedra - tzn. gdy sprawuje urząd pasterza i nauczyciela wszystkich wiernych, swą najwyższą apostolską władzą określa zobowiązującą cały Kościół naukę w sprawach wiary i moralności - dzięki opiece Bożej przyrzeczonej mu w osobie św. Piotra Apostoła posiada tę nieomylność, jaką Boski Zbawiciel chciał wyposażyć swój Kościół w definiowaniu nauki wiary i moralności” ${ }^{8}$. Naukę te powtórzył i wyjaśnił następny sobór:

\begin{abstract}
Ta nieomylność, w którą Boski Zbawiciel zechciał wyposażyć Kościół w określaniu nauki wiary lub obyczajów, ma taki zakres, jak depozyt boskiego objawienia, który ma być ze czcią przechowywany i wiernie wykładany. Nieomylnością tą z tytułu swego urzędu cieszy się Biskup Rzymski, Głowa Kolegium Biskupiego, gdy jako najwyższy pasterz i nauczyciel wszystkich wiernych Chrystusowych, który braci swych umacnia w wierze, ogłasza definitywnym aktem naukę dotyczącą wiary i obyczajów. Toteż orzeczenia jego słusznie zwane są nienaruszalnymi same z siebie, a nie na mocy zgody Kościoła, jako że ogłoszone zostały z pomocą Ducha Świętego przyrzeczona mu w osobie św. Piotra i dlatego nie potrzebują niczyjej aprobaty ani nie dopuszczają odwoływania się do niczyjego sądu. Wówczas bowiem Biskup Rzymski nie wyraża sądu jako prywatna osoba, lecz jako najwyższy nauczyciel Kościoła powszechnego, któremu przysługuje w szczególniejszy sposób charyzmat nieomylności ${ }^{9}$.
\end{abstract}

Na podstawie powyższych stwierdzeń soborowych można wskazać właściwe kryteria nieomylnego nauczania papieża:

- podmiotem nieomylności jest każdorazowy papież, a nie Stolica Apostolska jako instytucja,

- występuje jako najwyższy pasterz i nauczyciel wszystkich wiernych, czyli ex cathedra,

- świadomie angażuje całą pełnię swojej najwyższej władzy nauczycielskiej,

- ogłoszoną definitywnie daną prawdą zobowiązuje wszystkich wiernych (kategoryczny akt, a nie tylko zalecenia, rady, upomnienia czy perswazje), przy tym wola definicji dogmatycznej musi być formalnie wyrażona,

- zakres nieomylności jest taki sam, jak nieomylność całego episkopatu, w dziedzinie wiary i moralności,

\footnotetext{
${ }^{8}$ BF II 61 (DS 3073).

${ }^{9}$ KK 25.
} 
- nauczanie to, opierając się na pomocy Ducha Świętego, nie potrzebuje niczyjej aprobaty, ani nie dopuszcza żadnej apelacji ${ }^{10}$.

Dodać jednak należy, że zarówno papież, jak i cały Urząd Nauczycielski Kościoła są uwarunkowani i niejako związani słowem Bożym, zmysłem wiary całego Kościoła, tradycją Kościoła, w szczególności wyrażaną nauczaniem soborów oraz powinnością głoszenia prawdy objawionej w sposób dostępny dla ludzi danej epoki i kultury ${ }^{11}$.

Kluczową w tym wypadku sprawą jest rozróżnienie między nauczaniem zwyczajnym papieża (magisterium ordinarium) i jego nauczaniem uroczystym (magisterium extraordinarium, solemne), nazywanym symbolicznie ex cathedra. Przez nauczanie zwyczajne rozumie się niemal całość nauczania papieża: bulle, konstytucje apostolskie, motu propria, encykliki, adhortacje, homilie, konferencje, przemówienia itp. oraz akty wydawane w imieniu papieża przez kongregacje i inne urzędy Stolicy Apostolskiej. Natomiast nauczanie uroczyste ma miejsce w wyżej opisanych warunkach. Tu należy jednak dodać, że pomoc Boża jest udzielona papieżowi także wtedy, gdy nie formułuje nauki nieomylnej i nie wypowiada się w sposób definitywny, ale wypełnia swój zwyczajny urząd nauczycielski i podaje pouczenia, które prowadzą do lepszego zrozumienia Objawienia. I temu nauczaniu wierni winni okazywać religijną uległość ducha ${ }^{12}$.

Do tej pory faktyczne nauczanie uroczyste ex cathedra miało miejsce jedynie dwa razy: ogłoszenie dogmatu Niepokalanego Poczęcia (Pius IX, 1854 r.) i ogłoszenie dogmatu wniebowzięcia Matki Bożej (Pius XII, 1950 r.).

\section{TRAGEDIA NIEOMYLNOŚCI}

Sformułowanie „tragedia nieomylności” miało być wyrazem dezaprobaty przeciwników dogmatu o nieomylności papieża w formie z 18 lipca 1870 r., którego ogłoszenie spowodowało poważne spory wewnątrz Kościoła i doprowadziło do realnego podziału, czyli powstania Kościoła starokatolickiego $^{13}$. Należy też pamiętać, że nawet sprzeciwiającym się nowej formule dogmatycznej nie chodziło o całkowite jej odrzucenie, ale o jej inne brzmienie,

\footnotetext{
${ }^{10}$ BARTNIK, Dogmatyka katolicka, 239-240.

${ }^{11}$ Józef KRASIŃSKI, Z kart Magisterium Kościoła (Sandomierz: Wydawnictwo Diecezjalne, 1998), 15.

${ }^{12} \mathrm{KK} 25$.

${ }^{13} \mathrm{Na}$ ten temat zob. Klaus SCHATZ, Vaticanum I 1969-1970, t. III (Paderborn-MünchenWien-Zürich: Herder, 1994).
} 
które realnie wiązałoby papieża z Kościołem. Następca św. Piotra miałby być nieomylny, gdy wyrażałby głos całego Kościoła, jako jego rzecznik i reprezentant. Argumentacją za tego typu poglądem była refleksja historyczna ukazująca pierwsze tysiąclecie chrześcijaństwa, jako doświadczenie budowania doktryny, wynikającej nie z pojedynczych wypowiedzi i dokumentów, ale na podstawie całej kościelnej praktyki, czyli mozolnego i trudnego procesu budowania konsensusu. Odrzucano w ten sposób obraz papieża, jako nauczyciela wiary, który w pewnym sensie „na skróty”, na zasadzie szybkiego doktrynalnego orzeczenia, na drodze szczególnego, bezpośredniego boskiego „oświecenia” rozwiązywałby skomplikowany proces poszukiwania prawdy ${ }^{14}$. W debacie przypominano poglądy św. Antonina z Florencji, który twierdził, że papież nie jest nieomylny, gdy ogłasza definicję z własnej inicjatywy, ale tylko wtedy, gdy korzysta $\mathrm{z}$ rady i pomocy całego Kościoła. Tradycja i świadectwo Kościoła są tu kluczowe i nieredukowalne ${ }^{15}$.

Należy pamiętać, że Sobór Watykański I nie został formalnie zamknięty, jednak wybuch wojny niemiecko-francuskiej i jej skutki, włącznie z upadkiem Państwa Kościelnego, sprawił niemożliwość wznowienia obrad. Praktycznie wszyscy protestujący biskupi, którzy podkreślili swoje stanowisko wcześniejszym wyjazdem, będąc nieobecnym na uroczystej promulgacji, w różnych okolicznościach podporządkowali się rychło soborowej defini$\mathrm{cji}^{16}$. Jako symboliczne wydarzenie, w pewnym sensie zamykające debatę urzędową można traktować Oświadczenie episkopatu niemieckiego na temat stosunku prymatu do urzędu piotrowego (1875). Był to wyważony głos odrzucający skrajne koncepcje, zarówno koncyliaryzmu, sytuującego sobór nad papieżem, jak i papalizmu, waloryzującego urząd następcy Piotra ponad całym Kościołem. Pius IX zaaprobował ten dokument własnym listem apostolskim Mirabilis illa Constantia z 4 marca 1875 r. Zwracając się do biskupów niemieckich, stwierdził, że „wasze oświadczenie przypomina pierwotne, katolickie, a zatem właściwe twierdzenie świętego soboru i Stolicy Świętej, tak bardzo trafnie obwarowane znakomitymi i pewnymi dowodami i tak przejrzyście wyjaśnione, aby każdemu uczciwemu człowiekowi wykazać, że w atakowanych orzeczeniach nie ma niczego nowego lub czegoś, co

\footnotetext{
${ }^{14}$ Klaus Schatz, Sobory powszechne. Punkty zwrotne w historii Kościoła (Kraków: Wydawnictwo WAM, 2001), 251.

${ }^{15}$ Bogdan FERDEK, „Spór o nieomylność papieża. Od 'Haec sancta' do 'Pastor aeternus '”, Poznańskie Studia Teologiczne nr 29 (2015): 187.

${ }^{16}$ Günter DETTMER, Die ost- und westpreussichen Verwaltunsbehörden im Kulturkampf (Heidelberg: Quelle \& Meyer, 1958), 37.
} 
dokonywałoby zmiany w dawnych stosunkach i co mogłoby dostarczyć komuś pozoru dla powodowania wstrząsu w Kościele" ${ }^{17}$.

Problem jednak nie został do końca rozwiązany. Pozostał, czy wręcz narastał przede wszystkim w przestrzeni akademickiej oraz pośród wykształconych kręgów mieszczańskich Niemiec, Austrii i Szwajcarii. Do przeciwników dogmatu zaliczało się szereg niemieckich teologów, z profesorem Uniwersytetu Monachijskiego Ignazem Döllingerem na czele, który stał się symbolem zaistniałej schizmy w Kościele. Jeszcze w trakcie obrad soborowych, wraz z grupą zwolenników opublikował pracę: Der Papst und das Konzil, w której podjął krytykę procedowanego dokumentu oraz wykazał błędy w nauczaniu papieża, oskarżając go o chęć powrotu do stosunków średniowiecznych ${ }^{18}$. Innym ośrodkiem sprzeciwu był Wydział Teologiczny Śląskiego Uniwersytetu Friedricha Wilhelma we Wrocławiu, którego profesor Joseph Reinkens, późniejszy rektor (1865/66), został 14 czerwca 1873 r. pierwszym starokatolickim biskupem. Według niego Sobór Watykański I zniósł episkopat na rzecz papieża, który został uczyniony jakby „wice-Bogiem”. To nieuprawnione wywyższenie papieża, kosztem biskupów i niezgodne $\mathrm{z}$ Ewangelią, nazywał wprost „samobójstwem Kościoła”19. Również Warmia stała się miejscem poważnego sporu, gdyż szereg księży tej diecezji nie poddało się woli Vaticanum I. Poza Królewcem i Elblągiem największym rezonansem odbił się konflikt z profesorami Liceum Hosianum, Katolickiego Seminarium Nauczycielskiego oraz Katolickiego Gimnazjum Braniewskiego, którego symbolem był Paul Wollmann ${ }^{20}$. Wszyscy wymienieni profesorowie $w$ swoich diecezjach zostali ekskomunikowani. Należy podkreślić, że ostatecznie żaden biskup, jako uczestnik soboru i przeciwnik ogłoszonego dogmatu nie odłączył się od Rzymu. Ostatnim, który „podporządkował się” i zaakceptował orzeczenia soboru w 1881 r., za pontyfikatu Leona XIII, był biskup Bośni Josip Strossmayer ${ }^{21}$.

To, co udało się w wymiarze hierarchicznym, niestety w kontekście całej wspólnoty eklezjalnej się nie powiodło. Wymiernym i sformalizowanym sygnałem był głos świeckich katolików, określany jako apel z Königswinter

\footnotetext{
${ }^{17}$ PIUS IX, „List Apostolski Mirabilis illa constantia do biskupów niemieckich 4 marca 1875”, w Breviarium Fidei. Wybór doktrynalnych wypowiedzi Kościoła, red. Ignacy Bokwa (Poznań: Księgarnia Świętego Wojciecha, 2007), 271-272.

${ }^{18}$ Ignatz Döllinger, Der Papst und das Konzil, Rivingstons (London-Oxford-Cambridge, 1869), dostęp: 20.12.2019, http://www.archive.org/stream/a577134500dolluoft\#page/n5/mode/2up

${ }^{19}$ Joseph REINKENS, Über päpstiche Unfehlbarkeit: enige Reflexionen (München, 1870), 144-158.

${ }^{20}$ Janusz JASIŃSKI, „Początek ostrego konfliktu monarchii pruskiej z Kościołem katolickim a kwestia braniewskich starokatolików (1870-1872)", w Posłannictwo Biskupa Rzymu, red. Jacek Jezierski (Olsztyn: Wyższe Seminarium Duchowne Metropolii Warmińskiej Hosianum, 2002), 249.

${ }^{21}$ SCHATZ, Sobory, 257.
} 
(14 sierpnia 1870). Był to protest wobec dogmatycznych określeń Vaticanum I, które, według sygnatariuszy, podjęto bez pełnej jednomyślności i wolności oraz w sprzeczności z tradycyjną wiarą Kościoła ${ }^{22}$. W podobnym duchu utrzymane były kolejne deklaracje: Oświadczenie Norymberskie (26 sierpnia 1870) i Oświadczenie Monachijskie z Zielonych Świat 1871 roku. Warta podkreślenia jest rola, jaką w tym czasie odegrał wspomniany już ks. prof. Ignaz Döllinger. W liście do swego biskupa pisał:

\begin{abstract}
Jako chrześcijanin, teolog, historyk i obywatel nie mogę przyjąć tej nauki. Jako chrześcijanin - bo jest ona niezgodna z duchem Ewangelii [...]. Jako teolog - albowiem cała prawdziwa tradycja Kościoła zwraca się przeciwko niej nieubłaganie. Jako znawca historii - gdyż jest mi wiadomo, że uporczywe dążenie do urzeczywistnienia panowania nad światem, właściwe tej doktrynie, kosztowało Europę strumienie krwi, doprowadziło do zamętu w wielu krajach i spowodowało ich upadek, rozbiło piękną organiczną strukturę starego Kościoła [...]. Wreszcie muszę je odrzucić jako obywatel, albowiem podnosząc swe pretensje do podporządkowania państw i monarchów i całego porządku politycznego władzy papieskiej oraz przez żądanie dla kleru stanowiska uprzywilejowanego w wewnętrznych prawach państwa, tworzy podstawę dla nieskończonego, niszczycielskiego rozdźwięku między państwem i Kościołem, między duchowieństwem i laikatem ${ }^{23}$.
\end{abstract}

Skutkiem jego inicjatyw i wystąpień przeciw uchwałom soboru była publiczna ekskomunika, która doprowadziła definitywnie do rozłamu. Trzy kongresy: w Monachium (22-24 września 1871), w Kolonii (20-22 września 1872) oraz w Konstancji (12-15 września 1873) usankcjonowały powstanie nowej rzeczywistości eklezjalnej - Kościoła starokatolickiego ${ }^{24}$.

Nieomylność jako problem teologiczny w dyskursie akademickim pojawił się po raz drugi w kontekście Soboru Watykańskiego II, którego nauczanie odniosło się do orzeczeń dogmatycznych Vaticanum I. Konstytucja dogmatyczna o Kościele nie tylko potwierdziła dogmat o nieomylnym nauczaniu Biskupa Rzymu, ale ukazała go w szerszym kontekście kolegium biskupiego i całej wspólnoty, opierając je na asystencji Ducha Świętego oraz nadprzyrodzonym zmyśle wiary całego Kościoła ${ }^{25}$.

Przeciwko tym tezom wystąpił duchowny szwajcarski, profesor teologii fundamentalnej w Tybindze Hans Küng, będący nota bene ekspertem nauko-

\footnotetext{
${ }^{22}$ Borys PRZEDPEŁSKI, „Sobór Watykański I i jego recepcja. Spojrzenie teologa starokatolickiego", w Posłannictwo Biskupa Rzymu, 68.

${ }^{23}$ Cyt. za: Wiktor Wysoczański, Polski nurt starokatolicyzmu (Warszawa: Zakład Wydawniczy Odrodzenie, 1977), 20.

${ }^{24}$ PRZEDPEŁSKI, „Sobór Watykański I”, 69.

${ }^{25}$ KK $25 ; 12$.
} 
wym na soborze. Wychodząc od tez zawartych w dokumentach dogmatycznych, stwierdził, iż w ścisłym znaczeniu nieomylny jest tylko Bóg i tylko On jest w każdym przypadku wolny od błędu, czyli z założenia nie może zwodzić ani dać się zwieść. Natomiast złożony z ludzi Kościół, który Bogiem nie jest, może na wszystkich poziomach i we wszystkich dziedzinach zwodzić siebie i innych. Küng twierdził, że żadna ludzka wypowiedź, w tym również dogmatyczna, nie może być nieomylna, właśnie dlatego, że jest ludzka. Ogłoszony na Soborze Watykańskim I dogmat o papieskiej nieomylności to według niego efekt samoobrony Kościoła przed gwałtownie zmieniającym się i wrogim mu światem, z liberalizmem i modernizmem na czele. Szwajcarski teolog odrzucając prawdę o nieomylności, przyjmował, iż Kościół, który pokornie jest posłuszny Biblii, ma udział w prawdzie samego Boga, który nie może zwodzić. To zasadnicze trwanie w prawdzie, które nie wyklucza błędów cząstkowych, nazywał niezniszczalnością lub niezawodniczością Kościoła. I dodawał, że busolą Kościoła jest nie papież, ale Biblia ${ }^{26}$. Po długim procesie wyjaśniającym, decyzją papieża Jana Pawła II, została mu odebrana misja nauczania teologii katolickiej.

\section{POSTULATY EKUMENICZNE}

Sobór Watykański II był wydarzeniem, w którym Kościół katolicki w sposób oficjalny włączył się w ruch ekumeniczny. Rozpoczęte w latach siedemdziesiątych dialogi bilateralne i multilateralne ukazały prymat Biskupa Rzymu z nieomylnym nauczaniem, jako jeden z najtrudniejszych problemów ekumenicznych, czy wręcz najtrudniejszy próg na drogach jedności. Poniżej zostaną przedstawione istotne postulaty formułowane $\mathrm{w}$ tej dziedzinie, traktując je jako eklezjologiczny problem ad intra.

Trudno mówić o wymiarze ekumenicznym obrad Vaticanum I, ponieważ w Kościele katolickim odczuwało się wtedy poważny sceptycyzm wobec rodzącego się ruchu zjednoczeniowego, a jako jedyną drogę do pełnej jedności chrześcijan widziano unionizm i konwertyzm. Tym niemniej obecni na soborze przedstawiciele Kościołów uniatyckich wprowadzali wątki o charakterze ekumenicznym, uwzględniające również problem nieomylności papieskiej. Symptomatyczny jest fakt, że żaden z biskupów wschodnich obrządków, poproszony o propozycje przyszłych tematów soborowych nie postulował do-

\footnotetext{
${ }^{26}$ Stanisław RABIEJ, „Zakres nieomylności Kościoła”, w Pokładamy nadzieję w Kościele, red. Dawid Mielnik (Opole: Koło Naukowe Teologów, 2016), 42.
} 
gmatycznego określenia nieomylności papieskiej, ogół za to domagał się unikania w obradach soborowych tego wszystkiego, co mogłoby utrudniać powrót do Kościoła odłączonych chrześcijan wschodnich ${ }^{27}$.

Stanowisko biskupów wschodnich w sprawie ogłoszenia nieomylności papieża jako dogmatu wiary nie było jednolite, i to do tego stopnia, że linia podziału między „infallibilistami” a ,antyinfallibilistami” przebiegała przez sam środek poszczególnych obrządków. Znamiennym tego przykładem jest mały obrządek wschodni z językiem rumuńskim, w którym abp z Fagaras W. Vancsa był przeciwnikiem tej definicji, natomiast z Oradea Mare J. Papp-Szilagyi jej zwolennikiem. Również w chaldejskim, melchickim czy armeńskim obrządku nie wszyscy biskupi stali po stronie swoich patriarchów. Przyczyny takiego nastawienia wśród grona Ojców wschodnich są dzisiaj trudne do zrozumienia $^{28}$. Najogólniej ujmując można stwierdzić, że krytyka nauczania Soboru Watykańskiego I ze strony teologów pochodzących $\mathrm{z}$ innych denominacji chrześcijańskich, jak i części teologów katolickich, skupiała się na zarzucie zbytniego centralizmu i niedocenianiu znaczenia wspólnoty wierzących, którzy, jako cały Kościół, są prawdziwym podmiotem nieomylności w wierze i obyczajach.

Nieomylność Biskupa Rzymu stała się istotnym punktem dialogu ekumenicznego po Soborze Watykańskim II. Poszczególne komisje bilateralne z udziałem Kościoła katolickiego i promulgowane dokumenty umiejscawiały nieomylność po stronie najtrudniejszych kwestii do rozwiązania. Należy zaznaczyć, że nieomylność papieska nie była nigdy wprost tematem debaty ekumenicznej, ale raczej pojawiała się w dyskusji poświęconej posłudze Następcy św. Piotra, rozumiana jako element funkcji prymacjalnej, czyli prymat nauczania. Najogólniej można stwierdzić, że $\mathrm{w}$ żadnej $\mathrm{z}$ oficjalnych komisji nie wypracowano formuły możliwej do wzajemnej akceptacji.

W dialogu katolicko-luterańskim zagadnienie prymatu i nieomylności pojawiło się w dokumencie podsumowującym pierwszy etap prac teologów w latach siedemdziesiątych XX wieku, Ewangelia $i$ Kościót, który potocznie nosi nazwę Raport z Malty. Funkcję prymacjalną poddawano analizie w nowej perspektywie interpretacyjnej, biorąc pod uwagę służbę na rzecz wspólnoty i jej jedności. Uznano potrzebę istnienia ogólnokościelnej instytucji, która skutecznie służyłaby jedności wszystkich chrześcijan. Nie wykluczono, by mógł być to urząd papieski,

\footnotetext{
${ }^{27}$ Edmund PrzeKOP, „Tendencje ekumeniczne w wypowiedziach przedstawicieli Kościołów wschodnich na I Soborze Watykańskim”, Prawo Kanoniczne nr 3-4 (1972): 62.

${ }^{28}$ Johannes BEuMER, "Ökumenische Tendenzen auf dem Ersten Vaticanum", Theologie und Philosophie nr 45 (1970): 390.
} 
po dokonanej reinterpretacji teologicznej i prakseologicznej jego struktury, zakładającej prymat Ewangelii ${ }^{29}$.

Najbardziej wyraziście kwestia ta pojawiła się w dialogu anglikańsko-katolickim. Prymat i nieomylność analizowane były jako istotne problemy w pracach międzynarodowej komisji ARCIC I i II $^{30}$. Znaczącym faktem było ukazanie korelacji dwóch wymiarów posługi biskupiej: prymacjalnej i koncyliarnej oraz potrzebę posługi na poziomie uniwersalnym (ministry of primacy) w przyszłym zjednoczonym Kościele. Stwierdzenie to bynajmniej nie zmieniło powszechnego poglądu teologów anglikańskich co do nieomylności, której nie mogli przyjąć w rozumieniu katolickim, gdyż według nich niemożliwe jest, by „z urzędem Biskupa Rzymu związany był nieodłącznie dar Bożej pomocy w orzekaniu, którego mocą jego formalne rozstrzygnięcia można uznać za pewne, zanim jeszcze zostaną one przyjęte przez wiernych" ${ }^{\text {"31. }}$. Ze strony anglikańskiej więc akceptacja wiernych, czy inaczej: powszechna recepcja jest warunkiem koniecznym do uznania rozstrzygnięć dogmatycznych czy to papieża, czy soboru, jako wolnych od błędu. Jest to jednak pogląd niemożliwy do akceptacji ze strony katolickiej, gdyż, jak wyraziła to Kongregacja Nauki Wiary: „dla Kościoła katolickiego gwarancją pewności orzeczonej prawdy nie jest uznanie ze strony wiernych, że prawda ta jest zgodna z Pismem Świętym i Tradycją, lecz samo autorytatywne orzeczenie autentycznych nauczycieli”" ${ }^{32}$. Wątpliwości strony katolickiej wzbudziło określenie indefectbility wolność od braku, które nie jest równoznaczne z pojęciem zastosowanym przez Sobór Watykański I, a mianowicie infallibilitas. Użyte zaś zostało, by podkreślić pewność Kościoła dotyczącą głoszonej prawdy Ewangelii, która jest obecna $\mathrm{w}$ sposób nieulegający wątpliwości w świadectwie następcy św. Piotra, gdy spełnia swój urząd utwierdzania swoich braci ${ }^{33}$. Jeśli więc można mówić o pewnym zbliżeniu między anglikanami i katolikami w kwestii

${ }^{29}$ „Ewangelia a Kościół. 'Raport z Malty””, w Wszyscy pod jednym Chrystusem. Ogólnokościelny dialog katolicko-luterański, cz. 1, 1965-1981, red. Stanisław Celestyn Napiórkowski (Lublin: RW KUL, 1985),117-137.

${ }^{30}$ Wypracowane dokumenty: Autorytet w Kościele (1976), Wyjaśnienia z Windsor (1981), Autorytet w Kościele (1981), Dar autorytetu (1991).

${ }^{31}$ ARCIC I. „Authority in the Church II”, w The Final Report, Windsor CTS/SPCK/Forward Movement (London-Cincinnati, 1982), 81-98.

${ }^{32}$ Kongregacja NAuKi Wiary, „Katolicka odpowiedź na Raport końcowy Międzynarodowej Komisji Anglikańsko-Rzymskokatolickiej, 6 grudnia 1991”, w Ut unum sint. Dokumenty Kościoła katolickiego na temat ekumenizmu 1982-1998, red. Stanisław Celestyn Napiórkowski i in. (Lublin: TN KUL, 2000), 120-127.

${ }^{33}$ Kongregacja NaUki Wiary, „Uwagi o Raporcie Końcowym ARCIC I, The Co-Chairmen”, w W trosce o petnię wiary, 181-190. 
prymacjalnej oraz uznanie w posłudze Biskupa Rzymu szczególnej misji rozpoznawania i wyrażania prawdy zbawczej, to mimo to jest ona źródłem wielu nieporozumień, zaś okoliczności i warunki nieomylnych wypowiedzi papieża są wciąż niejasne ${ }^{34}$.

W dialogu katolicko-prawosławnym trudno wskazać istotne uzgodnienia, gdyż kwestia prymatu nie pojawiła się w nim explicite. Nie można więc mówić o jakiejkolwiek akceptacji powszechnej jurysdykcji czy nieomylnego nauczania Biskupa Rzymu. Dla prawosławnych teza dogmatyczna o nieomylności papieża, która eliminuje konieczność zwoływania soborów jako jedynej dla nich instancji powołanej do wypowiadania się w kwestiach wiary i moralności, jest trudna do przyjęcia. Prawosławni nauczają, że tylko sobór ma możliwość ujęcia w słowa treści wiary, biskup zaś musi przestrzegać zgodności swoich wypowiedzi z Tradycją i wiarą Kościoła. Orzeczenie papieża ex cathedra pozbawia możliwości zbadania, czy jego wypowiedź pozostaje $\mathrm{w}$ zgodności z wiarą Kościoła. Takie pojmowanie prymatu papieża oznacza zakwestionowanie zasady soborowości w życiu Kościoła ${ }^{35}$.

Tego typu poglądy u wielu teologów prawosławnych pojawiają się w kontekście trynitarnym, w którym dogmat o prymacie i nieomylności papieża jest konsekwencją wprowadzenia Filioque do dogmatu Trójcy Świętej. Eklezjologia byłaby $\mathrm{w}$ tym przypadku praktycznym wyrazem wiary w Jedynego Boga w Trójcy Świętej. Olivier Clement podkreśla, że sformułowania dogmatu Filioque utwierdziły pewien rodzaj jednostronnej zależności Ducha Świętego w stosunku do Syna. Ta zależność znajduje swoje odzwierciedlenie w Kościele, w którym działanie Ducha Świętego zostało podporządkowane hierarchii, a niekiedy przez nią stłumione. Kościół wtedy nie jest już rozumiany jako miejsce trwającej wciąż Pięćdziesiątnicy, lecz jako społeczna struktura o kształcie piramidalnym, z biegiem czasu coraz silniej scentralizowana, w której ostatnie słowo należy do Biskupa Rzymu - Wikariusza Chrystusa ${ }^{36}$.

Wskazany wyżej zbiór poglądów w syntetycznym ujęciu można ująć postulatywnie i określić jako konieczność korekty w sposobie rozumienia urzędu prymacjalnego, z przywilejem nieomylności, którą można określić jako „nawrócenie Piotra”. W tym kontekście, idąc za W. Hryniewiczem, należałoby

\footnotetext{
${ }^{34}$ Roman MAŁECKI, „Prymat papieski we współczesnych dyskusjach ekumenicznych”, Studia Włoctawskie nr 9 (2006): 129.

${ }^{35}$ Jerzy Tofiluk, Prymat biskupa Rzymu z perspektywy Kościoła prawosławnego, dostęp: 2.02.2020, https://psd.edu.pl/wp-content/uploads/2017/07/ Prymat_biskupa_Rzymu_z_perspektywy_Kosciola_prawoslawnego.pdf

${ }^{36}$ Olivier ClÉMENT, „Bunt ducha i tragedia podziału. Kryzys chrześcijaństwa zachodniego”, Znak nr 2 (1992): 29.
} 
dzisiaj spojrzeć innym okiem na wypowiedzi tych biskupów uczestniczących w Soborze Watykańskim I, którzy byli przeciwni ogłoszeniu dogmatu o prymacie i nieomylności papieża. Stanowili oni zdecydowaną mniejszość, której ostrzeżenia zostały zignorowane. Według tego teologa, być może to oni właśnie byli wyrazicielami autentycznej świadomości Kościoła, kiedy obawiali się, iż w następstwie dogmatyzacji nieomylności papieskiej biskupi staną się jedynie - w ogromnej diecezji świata - wikariuszami papieża, wyniesionego do rangi superbiskupa ${ }^{37}$.

Można więc stwierdzić, że implikacją prowadzonego dialogu ekumenicznego jest apel o reinterpretację dotychczasowego nauczania Kościoła o prymacie Biskupa Rzymu, w tym oczywiście i jego charyzmatu nieomylności. Kierunek debaty eklezjologicznej mogą wyznaczać pytania, które postawił W. Kasper: a) nie podważając ważności orzeczeń dogmatycznych Soboru Watykańskiego I, należy zapytać, czy niektóre późniejsze interpretacje dogmatu papieskiego, jakie rozwinęły się jeszcze w XIX wieku, rzeczywiście harmonizują $\mathrm{z}$ całą Tradycją Kościoła oraz $\mathrm{z}$ samą istotą dogmatycznych definicji Soboru? b) które elementy orzeczeń dogmatycznych zawartych w Pastor Aeternus są w sposób szczególny związane ze specyficznym kontekstem i wyzwaniami, z jakimi Kościół katolicki musiał się zmierzyć w drugiej połowie XIX wieku? c) co należy uważać za treść istotną i niezmienną, a co za zmienną, gdyż związaną tylko $\mathrm{z}$ historycznym kontekstem tychże definicji ${ }^{38}$

W refleksji eklezjologicznej dotyczącej analizowanego powyżej zagadnienia podkreśla się, że nieomylność jest przymiotem Boga. Aplikacja tego pojęcia w posługę papieską musi zakładać tę prawdę. Choć bardziej adekwatnym byłoby być może określenie „bezbłędność”, jednak zaistniało ono w doktrynie kościelnej, co powoduje konieczność podkreślania, że nieomylne nauczanie następcy św. Piotra partycypuje w nieomylności Boga, który zachowuje je od błędu. Papieską nieomylność należy widzieć jako charyzmat, dzięki któremu, po spełnieniu określonych warunków, nauczanie Biskupa Rzymu jest wolne od błędów ${ }^{39}$.

\footnotetext{
${ }^{37}$ Wacław Hryniewicz, „Pytania o prymat”, Tygodnik Powszechny nr 4 (1998): 9

${ }^{38}$ Walter KASPER, „Il ministero petrino”, Il Regno - documenti nr 48 (2003): 439.

${ }^{39}$ Wolfgang BEINERT, „Unfehlbarkeit”, w Lexikon für Theologie und Kirche, t. X, red. Walter Kasper (Freiburg-Basel-Wien: Herder, 2006), 389.
} 


\section{BIBLIOGRAFIA}

ARCIC I. „Authority in the Church II”. W The Final Report, 81-98. Windsor CTS/SPCK/ Forward Movement London-Cincinnati, 1982.

BALTER, Lucjan. Nieomylność encyklik papieskich. Studium teologiczno-historyczne. Warszawa: Akademia Teologii Katolickiej, 1975.

BARTniK, Czesław Stanisław. Dogmatyka. T. II. Lublin: Wydawnictwo KUL, 2003.

BEINERT, Wolfgang. „Unfehlbarkeit”. W Lexikon für Theologie und Kirche, red. Walter Kasper, t. II, 389-390. Freiburg-Basel-Wien: Herder, 2006.

Beumer, Johannes. „Ökumenische Tendenzen auf dem Ersten Vaticanum”. Theologie und Philosophie $\mathrm{nr} 45$ (1970): 385-397.

CLÉMENT, Olivier. „Bunt ducha i tragedia podziału. Kryzys chrześcijaństwa zachodniego”. Znak nr 2 (1992): 27-38.

DetTmer, Günter. Die ost- und westpreussischen Verwaltungsbehörden im Kulturkampf. Heidelberg: Quelle \& Meyer, 1958.

Döllinger, Ignatz. Der Papst und das Konzil, Rivingstons. London-Oxford-Cambridge, 1869. Dostęp: 20.12.2019. http://www.archive.org/stream/a577134500dolluoft\#page/n5/mode/2up

„Ewangelia a Kościół. 'Raport z Malty”. W Wszyscy pod jednym Chrystusem. Ogólnokościelny dialog katolicko-luterański. Cz. 1, 1965-1981, red. Stanisław Celestyn Napiórkowski, 117-137. Lublin: RW KUL, 1985.

FERDEK, Bogdan. „Spór o nieomylność papieża. Od 'Haec sancta' do 'Pastor aeternus””. Poznańskie Studia Teologiczne nr 29 (2015): 183-196.

Hryniewicz, Wacław. „Pytania o prymat”. Tygodnik Powszechny nr 4 (1998): 9.

IRENEUSz z Lyonu. Adversus haereses III, 24, 2. Seria: Antologia patrystyczna, red. Andrzej Bober, 48-76. Kraków: Wydawnictwo Apostolstwa Modlitwy, 1966.

JASIŃSKI, Janusz. „Początek ostrego konfliktu monarchii pruskiej z Kościołem katolickim a kwestia braniewskich starokatolików (1870-1872)”. W Posłannictwo Biskupa Rzymu, red. Jacek Jezierski, 241-265. Olsztyn: Wyższe Seminarium Duchowne Metropolii Warmińskiej Hosianum, 2002.

KASJANIUK, Elżbieta. „Nieomylność”. W Encylopedia katolicka, t. XII, 1148. Lublin: TN KUL, 2009.

KASPER, Walter. „Il ministero petrino”. Il Regno - documenti $\mathrm{nr} 48$ (2003): 432-439.

KongregaCJa NAUKI WiaRY. „Katolicka odpowiedź na Raport końcowy Międzynarodowej Komisji Anglikańsko-Rzymskokatolickiej, 6 grudnia 1991”. W Ut unum sint. Dokumenty Kościoła katolickiego na temat ekumenizmu 1982-1998, red. Stanisław Celestyn Napiórkowski i inni, 120-127. Lublin: TN KUL, 2000.

Kongregacja Nauki Wiary. „Uwagi o Raporcie Końcowym ARCIC I, The Co-Chairmen”. W W trosce o petnię wiary. Dokumenty Kongregacji Nauki Wiary 1966-1994, 181-190. Tarnów: Biblos, 1995.

KRASIŃSKI, Józef. Z kart Magisterium Kościoła. Sandomierz: Wydawnictwo Diecezjalne, 1998.

„Mysterium Ecclesiae. Deklaracja o katolickiej doktrynie o Kościele przeciw niektórym współczesnym błędom". W W trosce o petnię wiary. Dokumenty Kongregacji Nauki Wiary 19661994, 54-64. Tarnów: Biblos, 1995.

PIUS IX. „List Apostolski Mirabilis illa constantia do biskupów niemieckich 4 marca 1875”. W Breviarium Fidei. Wybór doktrynalnych wypowiedzi Kościoła, red. Ignacy Bokwa, 271-272. Poznań: Księgarnia Świętego Wojciecha, 2007. 
PRZEDPEŁSKI, Borys. „Sobór Watykański I i jego recepcja. Spojrzenie teologa starokatolickiego”. W Posłannictwo Biskupa Rzymu, red. Jacek Jezierski, 59-71. Olsztyn: Wyższe Seminarium Duchowne Metropolii Warmińskiej Hosianum, 2002.

PRZEKOP, Edmund. „Tendencje ekumeniczne w wypowiedziach przedstawicieli Kościołów wschodnich na I Soborze Watykańskim”. Prawo Kanoniczne nr 3-4 (1972): 61-80.

RABIEJ, Stanisław. „Zakres nieomylności Kościoła”. W Pokładamy nadzieję w Kościele, red. Dawid Mielnik, 43-52. Opole: Koło Naukowe Teologów, 2016.

REINKENS, Joseph. Über päpstliche Unfehlbarkeit: enige Reflexionen. München, 1870.

RUSECKI, Marian. Traktat o Objawieniu. Kraków: Wydawnictwo Księży Sercanów, 2007.

SCHATZ, Klaus. Sobory powszechne. Punkty zwrotne w historii Kościoła. Kraków: Wydawnictwo WAM, 2001.

SchATZ, Klaus. Vaticanum I 1969-1970. T. III. Paderborn-München-Wien-Zürich: Herder, 1994.

TofiluK, Jerzy. Prymat biskupa Rzymu z perspektywy Kościoła prawosławnego. Dostęp: 2.02.2020. https://psd.edu.pl/wpcontent/uploads/2017/07/Prymat_biskupa_Rzymu_z_perspektywy_Kosciola_prawoslawnego.pdf

WYSOCZAŃSKI, Wiktor. Polski nurt starokatolicyzmu. Warszawa: Zakład Wydawniczy Odrodzenie, 1977.

\section{NIEOMYLNOŚĆ BISKUPA RZYMU \\ JAKO PROBLEM EKLEZJOLOGICZNY AD INTRA I AD EXTRA}

\section{Streszczenie}

Artykuł przedstawia problem nieomylności papieskiej w debacie eklezjologicznej wewnątrz Kościoła katolickiego oraz $\mathrm{w}$ kontekście dialogu ekumenicznego, prowadzonego $\mathrm{z}$ innymi wyznaniami chrześcijańskimi. Punktem wyjścia jest wyjaśnienie tego pojęcia oraz główne zagadnienia zawarte w dogmacie o nieomylności Biskupa Rzymu, ogłoszonym na Soborze Watykańskim I. Istota kontrowersji, które pojawiły się już w trakcie obrad Vaticanum I oraz po jego zakończeniu, polegała na ukazaniu relacji nieomylności Kościoła i nieomylności samego papieża: czy następca Piotra jest niezależny w definiowaniu prawd wiary. Brak konsensusu doprowadził do schizmy i powstania Kościoła starokatolickiego i ekskomuniki wielu teologów. Współcześnie nieomylność papieska jako problem eklezjologiczny obecna jest w dialogu ekumenicznym, w którym poszukiwana jest nowa jej formuła.

Słowa kluczowe: nieomylność; dogmat; papież; Kościół; ekumenizm. 